\title{
Editorial introduction to special focus: The rule of law in sub-Saharan Africa: Reflections on promises, progress, pitfalls and prospects
}

\author{
Charles M Fombad* \\ Professor of Law, Institute for International and Comparative Law, \\ Faculty of Law, University of Pretoria, South Africa
}

Eric Kibet**

Senior Lecturer, Moi University, Kenya

Serious efforts to entrench the rule of law in Africa came with the socalled third wave of democratisation in the 1990s. This democratic revival raised hopes of a new era of governance guided by the basic principles of constitutionalism, democracy, good governance, respect for human rights and respect for the rule of law. Promising signs of some progress have been overtaken by a steady decline, particularly in the last two decades.

For example, in the 2016 Ibrahim Index of African Governance Report, it is stated that, although during the last decade overall governance on the continent has improved, there has been a 'pronounced and concerning drop in safety and rule of law, for which 33 out of the 54 African countries - home to almost two-thirds of the continent's population - have experienced a decline since 2006, 15 of them quite substantially'. ${ }^{1}$ The conclusions arrived at in the Ibrahim Index of African Governance is largely supported by similar surveys, such as Freedom House's Freedom in the World Survey; the World Justice Project Rule of Law Index; the World Bank's World Governance Indicators; and Transparency International's Corruption Perception

* Licence-en-Droit (Yaoundé) LLM PhD (London); cfombad@up.ac.za

** LLB (Nairobi) LLM (Boston College) LLD (Pretoria); erickibet@gmail.com

1 See http://s.mo.ibrahim.foundation/u/2016/10/01184917/2016-Index-Report.pdf ?_ga $=1.210164309 .1550746377 .1489484030$ (accessed 20 March 2018). 
Index. In fact, in the latest Freedom in the World 2017, Freedom House notes that of the 11 countries in the world with the worst aggregate scores for political and civil liberties, six of these (Eritrea, South Sudan, Somalia, Sudan, Equatorial Guinea and the Central African Republic) are from sub-Saharan Africa. ${ }^{2}$ In a poll jointly conducted by The New York Times and the Pew Global Attitudes Project in 2006, a majority of Africans polled in ten sub-Saharan African countries indicated that they had been better off five years prior to the survey. ${ }^{3}$ Afrobarometer in its latest survey report on access to justice reveals that substantial barriers still inhibit citizens' access to justice in most African countries. While noting that countries differ greatly in the extent and quality of their citizens' access to justice, Afrobarometer points out that even the best-performing states have substantial work to do before they can claim to meet the call of the United Nations (UN) Sustainable Development Goal 16 for 'access to justice for all'. It notes that, for example, South Africa, which could be regarded as among the better performers, recorded a drop to 56 per cent (from 69 per cent ten years ago) of trust in courts. ${ }^{4}$

In light of such evidence, one can no longer be complacent about the dark clouds that are beginning to gather to imperil the few gains in terms of constitutionalism, democracy, good governance and respect for the rule of law that the 'third wave' brought. Given the importance of the rule of law as an instrument for promoting social, political, economic and social development, all of which are critical to peace and stability, the ominous decline in respect for the rule of law cannot be ignored. A two-day conference that took place at the Faculty of Law, University of Pretoria, South Africa, from 29 to 30 June 2017, jointly organised by the Institute for International and Comparative Law at the University of Pretoria and the Konrad Adenauer Stiftung Rule of Law Programme for Sub-Saharan Africa, Kenya, examined various aspects of the rule of law challenges facing Africa. A few selected papers presented during this conference appear in this section of the Journal. These start with an overview of the rule of law crisis. The articles deal with other topical issues, such as the rule of law and democracy; the rule of law and access to justice; the rule of law, discriminatory practices and social equalities; the rule of law and

2 See https://freedomhouse.org/report/freedom-world/freedom-world-2017?gclid=C jwKEAjwqZ7GBRC1srKSv9TV_iwSJADKTjaDbs23e9DVyVCU0xsjB-9nj1I-C0_Z5sclt0 HoNO3tPRoCN4_w_wcB (accessed 20 March 2018).

3 See P Shivute 'The rule of law in sub-Saharan Africa - An overview' http://www. kas.de/upload/auslandshomepages/namibia/HumanRights/shivute2.pdf (accessed 20 March 2018).

4 See Afrobarometer Policy Paper 39, 'Ambitious SDG goal confronts challenging realities: Access to justice is still elusive for many Africans' http://afrobarometer.org/ sites/default/files/publications/Policy\%20papers/ab_r6_policypaperno39_access_to _justice_in_africa_eng.pdf (accessed 20 March 2018). 
surveillance; and some aspects of monitoring and enforcing the rule of law in Africa.

In the introductory overview of the crisis of the rule of law in Africa that provides a general context of the challenges that Africa faces, Fombad starts by providing a detailed analysis of the meaning of the concept of the rule of law. He points out that because of its broad nature, there is no generally-agreed meaning of the concept of the rule of law. Nevertheless, Fombad indicates that there is now general recognition of the fact that it is a critical bulwark against insecurity, poverty and capricious and arbitrary government, and entails the observance of good laws that demand, at a minimum, good governance, accountability and the protection of human rights. Drawing from published surveys on the rule of law, Fombad demonstrates that for nearly two decades, there has been a steady decline in the state of the rule of law in Africa. This is of concern especially considering that even in countries that had recorded significant gains as far as the rule of law is concerned, there has been a steady decline, while some countries have consistently scored poorly over the years. Fombad recommends the enhancement of mechanisms for monitoring compliance and enforcement. He suggests that this should be done within the existing legal framework of the African Union (AU), such as the African Union Commission, the Peace and Security Council, and the African Peer Review Mechanism.

The rule of law is the bedrock on which democracy and democratic practices are supposed to be anchored. Although democracy in one form or another is well established through the regular holding of multiparty elections in sub-Saharan Africa, there are many signs of creeping authoritarianism. This is so not only in countries with a good record on democracy, such as Botswana and South Africa, but also in those countries that have used democracy as a charade behind which to dissimulate their despotism, such as Cameroon and Zimbabwe. Frimpong and Agyeman-Budu use the Ghanaian experience from independence to date as a case study for democracy and the rule of law. Their article takes us on a journey through the various phases of the rule of law and democracy situation in Ghana, from independence in 1957, through the period of military regimes, to date. The article exposes two problems facing the rule of law and democracy in contemporary Ghana: the security of tenure of judges and the appointment of members of parliament as ministers of state. The authors illustrate how the reasoning by the judges of the Supreme Court in the presidential election petition challenging the election of John Mahama failed to uphold the Constitution. The Court instead chose the convenient option and upheld the election of Mahama rather than to uphold the law and the cardinal democratic principle that elections must always reflect the wishes of the people. The authors argue that the Ghanaian courts on numerous occasions when given the opportunity to do so have failed to uphold the rule of law in their decisions. The article also raises an interesting point in its claim that the Constitution of Ghana inherently undermines the rule of law 
in Ghana in its indemnity clauses that bar the courts from challenging the actions of the military regimes. In conclusion, the authors suggest that there is need for a complete overhaul of the constitutional order if the rule of law is to be secured in Ghana.

Although access to justice has long been regarded as one of the important cornerstones of the rule of law, democracy, good governance and effective and equitable development, it unfortunately remains elusive to many ordinary citizens in sub-Saharan Africa. There are numerous causes of the challenges to access to justice. One dimension of this is explored in the article by Inman and Magadju, who examine international crimes, national trials and victim participation as an avenue to enhance the rule of law and addressing impunity in the Democratic Republic of the Congo (DRC). The article traces the origin of the right to victim participation and explores the position under the UN Basic Principles and Guidelines on the Right to a Remedy and Reparations for Victims of Gross Violations of International Human Rights Law and Serious Violations of Humanitarian Law; the European Convention on Human Rights (as interpreted by the European Court of Human Rights); Principles and Guidelines on the Right to a Fair Trial and Legal Assistance in Africa; the American Convention on Human Rights (as interpreted by the Inter-American Court of Human Rights); and the practice before the Extraordinary Chambers in the Courts of Cambodia (ECCC) and the military tribunals in the DRC. The authors observe that the participation of victims is essential as it recognises the victim's rights to retribution and enhances the notion of access to justice by victims. The article examines the practice of participation of victims before the ECCC, and suggests that the system provides a good model for the trials before the military tribunals trying international crimes committed during the conflicts in the DRC as it is based on the civil law tradition that is similar to that in the DRC. Furthermore, the article identifies various challenges that the trials before the military tribunals in the DRC face. This includes poor or a complete lack of representation of victims by competent lawyers; a lack of effective witness and victim protection; and high court fees, which make it impossible for many victims to realise reparations ordered by the courts. This, the authors observe, undermines access to justice by the victims of crimes and perpetrates the high level of impunity in the DRC as far as international crimes are concerned.

Another perspective to this is provided by Moyo in his article on standing, access to justice and the rule of law in Zimbabwe. Moyo evaluates the position of the law in Zimbabwe in respect of standing and how it affects access to justice and the rule of law broadly. He traces the rules of standing for constitutional claims under the now defunct Lancaster House Constitution, and shows how both the text of the Constitution as well as judicial declarations took very narrow and restrictive positions that effectively locked out legitimate claims for reasons that claimants did not have a 'direct and substantive' interest. The article uses several examples to illustrate how this 
position on standing resulted in cases being defeated and the courts failing to uphold constitutional rights on the basis of procedural technicalities. The article subsequently shows how the enactment of the current Constitution has largely cured this problem through broadening the scope of locus standi. Moyo shows that, under the current Constitution, courts can entertain claims for violations or threats of the violation of rights from persons who are directly affected as well as those suing on behalf of others or in the interests of the public. The article argues that this enhances access to justice, the protection of human rights and the rule of law.

Minorities - racial, religious, ethnic or others, such as foreigners have become targets in many instances when the rule of law is disregarded. This has raised complex issues of discrimination, marginalisation and social inequalities. Two articles discuss some aspects of these complex issues. Rudman looks at the position of women in the article 'Women's access to regional justice as a fundamental element of the rule of law: The absence of a committee on the rights of women in Africa and its effects on the enforcement of the African Women's Protocol'. The article focuses on the challenges facing the enforcement of women's rights in Africa before regional human rights enforcement institutions, such as the African Commission on Human and Peoples' Rights and the African Court on Human and Peoples' Rights. After pointing out that the concept of the rule of law entails several aspects of human rights, Rudman focuses on women's rights as a special feature of human rights that has received a significant boost in Africa through the adoption and wide ratification of the Protocol to the African Charter on Human and Peoples' Rights on the Rights of Women in Africa (African Women's Protocol). She then goes on to expose the internal and external weaknesses undermining the realisation of women's rights as guaranteed in the Women's Protocol. The emphasis is on the protection and enforcement of women's rights as an aspect of human rights guaranteed under African regional law. Rudman puts forward some practical ideas on what should be done to enhance respect for the rule of law as far as women's rights are concerned. She proposes amendments to the Protocol to create a Committee on the Rights of Women within the African Women's Protocol modelled after the CEDAW Committee. She also proposes that the African Commission should reconceptualise its approach to women's issues. Furthermore, she recommends amendments to allow the African Committee of Experts on the Rights of the Child to refer cases before it to the African Court. This, the article argues, would promote the enforcement of women's rights, as the Committee will act as a receiver of complaints with respect to violations as well as a driver or champion of the enforcement of the rights before the relevant institutions.

Hindeya examines the rule of law and the challenges that the rule of law in Ethiopia faces in respect of land rights of minority communities. He demonstrates that although the Constitution of Ethiopia protects the land rights of minority communities and gives 
regional states the power to manage land resources, the practice is at variance with these guarantees. Through the delegation of power by regional state government to the federal government as well as the far-reaching power and patronage of the ruling party, the federal government enjoys wide powers to deal with land. This purported delegation of powers, the article argues, is contrary to the letter of the Constitution and lacks basis in law. Pursuant to delegated powers, the article illustrates that the federal government in the recent past has transferred huge tracts of land to foreign investors without the consent or involvement of local communities. As a result, ethnic minorities in the Gambella and Benishangl-Gumuz regions of Ethiopia have been dispossessed and deprived of their land rights, with little or no recourse to justice, since the public generally have no confidence in the courts, especially on matters where the executive is the violator of the law.

One of the greatest threats posed to democracy and respect for the rule of law today is the misuse of personal data and the illegal use or misuse of information collected legally or illegally through surveillance. Most of the abuses have been associated with the fight against terrorism, which has been used as a pretext for frequent flagrant violations of human rights and the clamping down on legitimate opposition activities. Abdulrauf provides a general overview of this problem. Focusing on electronic surveillance and its legal framework in sub-Saharan Africa, Abdulrauf shows how electronic surveillance undermines the right to privacy and other human rights guaranteed by the law. He argues that electronic surveillance have more implications for the rule of law beyond the violation of the right to privacy. The article demonstrates that electronic surveillance also fosters serious abuses of power by the state, and often has a negative effect on the independence of the judiciary, among other tenets of the rule of law. After examining some of the measures necessary to entrench the rule of law in the use of electronic surveillance in the sub-Saharan region, Abdulrauf points out that there now is a commendable trend towards the development of sui generis laws to regulate electronic surveillance since privacy laws clearly are inadequate. Another dimension of this problem is examined by Gebreegziabher whose article looks at the right to privacy in the age of surveillance to counter terrorism in Ethiopia. He points out that in spite of being a useful tool to prevent and prosecute terrorism, surveillance is increasingly being utilised as an excuse for infringements on privacy in several jurisdictions. The article identifies legal and practical problems causing violations of the right to privacy while countering terrorism in Ethiopia. The analysis is substantiated by an empirical study involving key informant interviews and case file reviews from Ethiopian courts. His analysis suggests that there is widespread use of warrantless interceptions that are used as prosecution evidence in defiance of the law. He concludes that there is a need to ensure that counter-terrorism surveillance in Ethiopia is carried out in conformity with the law to reflect the values of a 
democratic society based on the rule of law and respect for the right to privacy.

The final article deals with the issue of monitoring and enforcing the rule of law in Africa. The contextual elements of the rule of law suggest that certain standards could be developed for assessing the rule of law at the level of the $A U$, regional economic communities and other international organisations. Hansen and Mue explore one of the possibilities for doing this. Their article is based on draft principles that, it is argued, can be beneficial to the International Criminal Court (ICC), civil society and other role players in the international criminal justice system. These draft principles are drawn from the experiences of the failed attempts to prosecute Kenyan cases linked to the postelection violence of 2007 before the ICC. The article shows how cooperation among member states is an obligation that cannot be assumed simply because it is required by the Rome Statute of the ICC. The authors demonstrate how co-operation with Kenya became a huge challenge during the proceedings as key suspects held powerful positions in the Kenyan government. It is worth noting that despite the referral by Kenya to the Assembly of State Parties (ASP) by the Court for non-co-operation, the ASP has not had and is unlikely to have the item on its agenda. The article also shows how the immunity of state officials is a complex issue. Whereas the position of suspects is irrelevant under the Statute, the article demonstrates how the cases against President Kenyatta and Vice-President Ruto became complicated because of their powerful official positions. The article compares this position with the proposals under the Protocol on Amendments to the Protocol on the Statute of the African Court of Justice and Human Rights (Malabo Protocol) of the AU to grant immunity to heads of state and senior government officials, and notes that in reality there may be no practical differences between the position of the Malabo Protocol and the Rome Statute, given the experiences of the Kenyan cases. On complementarity, the article points out how this principle faces serious challenges in view of the fact that states may not be interested in accountability for international crimes. The article also draws attention to the challenges experienced as far as witness protection and the participation of victims are concerned, and offers suggestions on how the situation could be improved. In setting out the Nairobi Principles on Accountability, the article shows how it offers practical training, advocacy and practical tools for role players in international criminal justice, such as the ICC, the AU, state parties and civil society. This, they conclude, would help to advance the cause of justice in Africa as far as accountability for international crimes is concerned, thereby reducing impunity and promoting respect for the rule of law.

A number of important conclusions may be drawn from these articles about the state of the rule of law in Africa. First, it is clear that there has been and continues to be a steady decline in the state of the rule of law in sub-Saharan Africa. This conclusion is based on and supported by various empirical studies and case studies presented in 
the articles. Second, the decline in the rule of law goes hand in hand with the reversal of democratic gains in various countries, such as the DRC, where the constitutional and democratic order has stalled. The trend is also characterised by violations of human rights and a corresponding inability of courts to intervene in an effective and meaningful manner. Third, the problem generally is not necessarily one of deficiency in the law to support the rule of law. The problem often is one of weakness in the enforcement framework and subservience or weakness of the judiciary in other situations. To address these challenges, there is a need for a more proactive engagement by the international community generally, but more specifically at the level of the $\mathrm{AU}$ and regional economic communities. Anticipating conflict situations and taking decisive action will go a long way towards arresting the decline in respect for the rule of law in African states. The experiences of the European Union framework provide a useful model to adopt, but this will require greater political will from the $\mathrm{AU}$ and member states of regional economic communities. Whilst arresting the continuing deterioration in respect for the rule of law will demand serious action by individual African states supported by the AU, ordinary citizens also have a special responsibility to actively monitor and put pressure on their governments to respect their national constitutions and relevant laws as well as their international commitments. 